\title{
La ley del divorcio de junio de 1981 en perspectiva histórica
}

\author{
Pablo Martín de Santa Olalla Saludes 1
}

\section{RESUMEN}

La Ley del divorcio fue uno de los asuntos más polémicos de la

corta gestión del Gobierno

Calvo-Sotelo, y demostró la fuerte diversidad ideológica que existia en la UCD, principalmente entre los demócratacristianos y los socialdemócratas. La cuestión fundamental que este estudio pretende dilucidar es si

realmente el problema era ideológicamente tan conflictivo o

si éste fue aprovechado para provocar la ruptura del partido; cuál fue la actitud de la Iglesia en todo este proceso; $y$ si ciertamente la sociedad demandaba la Ley del divorcio que finalmente se aprobó en el Parlamento, o ésta, al contrario, fue excesivamente progresista.

\section{ABSTRACT}

The Law for divorcment was one of the more polemic affairs during the short gobernment of President Calvo-Sotelo, and showed the strong ideologic diversity in the UCD, mainly between the christian-democrats and the socialdemocrats. The main question that this article wants to check is if really the problem was so strong ideologicly or if it was really used for breaking the political party; which was the behaviour of the Catholic church along the conflict; and if certainly the society was asking for the Law for divorcment that finally passed the Parliament, or if, on the other hand, was too progresist.

La cuestión del divorcio sufrió una importante transformación con el cambio de régimen político. Hasta la muerte de Franco, la aprobación de una ley civil que regulara la ruptura conyugal era absolutamente implan-

1 Este artículo ha sido posible gracias una beca de Formación del Personal Investigador (F.P.I.) otorgada por la Comunidad de Madrid. 
teable. Sin embargo, menos de dos años después, cuando llegó el momento de concurrir a las elecciones democráticas de junio de 1977 , ya tanto los socialistas como los comunistas ofertaban en sus respectivos programas la aprobación de una ley divorcista que fuera proclive a una fácil disolución de la unión conyugal. Su criterio se encontraría respaldado un año después por la propia Constitución de 6 de diciembre de 1978, que decía textualmente, en su artículo 32 , lo siguiente: «la ley regulará las formas de matrimonio, la edad y capacidad para contraerlo, los derechos y deberes de los cónyuges, las causas de separación y disolución y sus efectos" 2. Todo ello se hacía en función de una opinión pública que era mayoritariamente favorable a dicha regulación, aunque sobre la manera de hacerlo surgirían las discrepancias.

A la altura de 1977-78, ya comenzaron a mostrarse públicamente las primeras discrepancias en el seno de la jerarquía católica. En efecto, es posible detectar un enfrentamiento entre un sector mayoritario de la Conferencia Episcopal, que controlaba las decisiones de la misma y que hacía pública una determinada actitud ante el divorcio, y un grupo minoritario de obispos diocesanos que habían perdido todo su poder tras la muerte de Casimiro Morcillo en mayo de 1971. En el dominante las cabezas salientes eran Vicente Enrique y Tarancón, Cardenal-Arzobispo de Madrid, José María Bueno Monreal, Cardenal-Arzobispo de Sevilla, y Narciso Jubany, Cardenal-Arzobispo de Barcelona: los dos primeros eran, respectivamente, presidente y vicepresidente de la Conferencia Episcopal. Mientras, el sector minoritario y de clara tendencia conservadora, sólo tenía como hombre realmente representativo a Marcelo González, Cardenal Primado de Toledo, además de José Guerra Campos (Obispo de Cuenca), Laureano Castán (Sigüenza-Guadalajara), Segundo García de Sierra (Burgos), Pablo Barrachina (Orihuela-Alicante), Demetrio Mansilla (Ciudad Rodrigo), Ángel Temiño (Orense), Luis Franco (Tenerife) y Francisco Peralta (Vitoria) ${ }^{3}$. El divorcio iba a constituir, asi pues, una nue-

2 Constitución Española de 6 de diciembre de 1978. En cualquier caso, la Carta Magna de la Transición era bastante más positiva para los intereses de la Iglesia que la Constitución de 1931, como demuestra el articulo de GUNTHER, R. y BLOUGH, R. A.: "Conflicto religioso y consenso en España: Historia de dos constituciones», en Revista de Estudios Políticos, núm. 14, 1980, págs. 65-109.

3 Guerra Campos habia pasado de ser Secretario de la Conferencia Episcopal con Morcillo a perder el puesto en marzo de 1972 en beneficio de Elías Yanes, quien acabaría siendo presidente del máximo organismo episcopal entre 1993 y 1999. De todo el sector ultraconservador, sólo estaría presente en el Ejecutivo Marcelo González, algo inevitable dada su condición de Cardenal Primado, y, curiosamente, Laureano Castán, a quien se le encargó la Comisión para la Doctrina de la $\mathrm{Fe}$ (al frente del cual permanecería poco), seguramente en un intento por parte del 
va ocasión para mostrar una escisión existente desde hacía más de un lustro.

El primero en «abrir fuego" fue Pablo Barrachina 4 , quien publicó en febrero de 1977 una instrucción pastoral titulada «El divorcio y la opinión pública» 5 . Barrachina hacía un recorrido histórico para recordar, no sólo la doctrina contra el divorcio y a favor de la indisolubilidad del matrimonio existente desde Pío IX, sino la histórica oposición de los pontífices a la ruptura de la unión conyugal, incluso cuando se trataba de poderosos monarcas de sus respectivas épocas: desde el enfrentamiento de Nicolás I con el rey Lotario en el siglo IX, hasta el de Pío VII con Napoleón Bonaparte en 1810, sin olvidar el más famoso caso, el de Enrique VIII y las abiertas negativas tanto de Clemente VII y Pablo III. A su parecer, se habian dado varias razones rotundamente equívocas para esgrimir la posibilidad del divorcio, como la indebida distinción entre matrimonio y sacramento, el equívoco de que el matrimonio hace el «amor» y lo deshace su falta, o la apelación a la disolubilidad extrínseca por autoridad distinta de los cónyuges. A aquellos que habían afirmado que la indisolubilidad no afecta a los no católicos, Barrachina recordaba que todo matrimonio era indisoluble por Derecho Natural. Por ello, cualquier divorcio estatuido por el poder civil era, sencillamente, nulo, ya que la raiz de tales legislaciones se encontraba en una falsa interpretación de la soberanía y plenitud de poder de los Estados: éstos tenian como obligación reconocer y proteger los derechos de la persona humana, y entre ellos, el de la familia. El matrimonio era, en este sentido, anterior al Estado, por lo que éste no tiene nada que decir ante una hipotética disolución del vínculo conyugal. Barrachina, de esta manera, se adelantaba a la separación Iglesia-Estado que la Constitución de diciembre de 1978 instauraría poco menos de dos años después, asegurando que el divorcio era ajeno a cualquier cambio en las relaciones Iglesia-Estado.

sector progresista de no aislar totalmente a los antiguos colaboradores de Morcillo. En cualquier caso, el Ejecutivo que había salido en marzo de 1972 y que se mantendría durante un largo período tenía presente en su seno a todo el clero más renovador y partidario de la separación Iglesia-Estado: Enrique y Tarancón, Bueno Monreal, Jubany, Díaz Merchán, Cirarda... Sobre todo lo que fue la histórica renovación de la cúpula eclesial, encontramos un abundante relato en Enrique y Tarancón, V.: Confesiones. Madrid, PPC, 1996, págs. 510-514.

4 La revista Vida Nueva, uno de los medios de difusión del catolicismo más progresista, había afirmado con rotundidad cinco años antes que Barrachina pertenecía a la línea más conservadora del episcopado español. Vida Nueva, núms. 821-822, 26 de febrero-4 de marzo de 1972, pág. 57.

5 Veáse al respecto Boletín Oficial del Obispado de Orihuela-Alicante, núm. 107, febrero de 1977, págs. 3-19. 
Barrachina encontraría apoyo a sus palabras muy poco tiempo después, concretamente el 11 de febrero de 1977 y en el territorio de la provincia eclesiástica de Valladolid. El Arzobispo de Valladolid, José García Goldaraz, y los obispos de Ávila (Felipe Fernández), Ciudad Rodrigo (Mansilla), Salamanca (Mauro Rubio), Segovia (Antonio Palenzuela) y Zamora (Eduardo Martínez) publicaron un documento titulado «Estabilidad de la familia» 6 . Desde luego, se trata de un texto claramente más aperturista y menos dogmático que el de Barrachina. Para estos prelados, habia que saber conjugar tolerancia y respeto en ambas direcciones, tanto la que llevaba hacia el divorcio como la que potenciaba la estabilidad de la familia. En cualquier caso, el divorcio era considerado un mal moral y social, un peligro de contagio permanente e, incluso, un impulso hacia la decadencia moral. Las leyes han de ser capaces de concordar con los valores éticos. Es evidente que el pensamiento moral cristiano no es absolutamente rígido, y que admite la tolerancia en algunos casos si el objetivo es no provocar males mayores o conseguir otros bienes. Pero tal tolerancia no puede aplicarse si lo que hace una ley es fomentar el divorcio, provocando un aumento de las rupturas: las parejas no pueden divorciarse argumentando que se trata de una necesidad, sino que esto ha de ser posible en el momento en que la disolución del vínculo conyugal sea absolutamente inevitable y el mantenerlo contra viento y marea no haga más que generar nuevos problemas. En cualquier caso, el talante real del documento es nítidamente conservador, sobre todo cuando leemos la siguiente afirmación: «Introducir el divorcio en una ordenación legal se hace a través de una decisión que puede parecer razonable, pero es de una explosividad tal, que después se corre el riesgo de no poder dominar ya las consecuencias y de crear nuevas servidumbres que se opondrian a una verdadera liberación. A la vista está lo que sucede en los países divorcistas" 7 .

Pero, como hemos señalado anteriormente, la Conferencia Episcopal, dominada por el clero progresista desde junio de 1971 (oficiosamente) y

6 El documento puede encontrarse en los boletines respectivos de cualquiera de las diócesis citadas. Nosotros lo conocemos a través del Boietín Oficial del Obispado de Ciudad Rodrigo, nüm. 3, marzo de 1977, págs. 103-108.

7 lbídem, pág. 107. También dirian: “Como pastores de nuestro pueblo, pensamos que esa hipotética ley no sería un mal menor entre nosotros. Creemos que, aun queriendo resolver situaciones lamentables por todos conocidas y que merecen también el respeto de todos, la ley del divorcio ocasionaría males muy graves e irreparables en la sociedad española: entre otros, se crearían situaciones irreversibles en ciertas uniones conyugales y serviría de incitación a matrimonios sin problemas, pero débiles, solicitados de una manera cada vez más avasalladora por la permisividad del medio ambiente, sobre todo teniendo en cuenta que por parte del pueblo es fácil confundir lo legal con lo moral, cuando en realidad no todo lo permitido legalmente es ético". 
marzo de 1972 (oficialmente), prefirió caminar por otros derroteros. La cuestión era sumamente difícil: doctrinalmente no podian hacer otra cosa que oponerse al divorcio, pero, políticamente, tras haber conseguido que menos de un año antes el Rey renunciara al privilegio de presentación de obispos, no se debía dificultar aún más el complejísimo proceso de democratización de las instituciones políticas y de la propia sociedad. Recordemos, en este sentido, que en noviembre de 1976 había sido aprobada la Ley para la Reforma Política, puerta que abrió el camino de manera definitiva a la democracia, y que a la altura de enero-febrero de 1977 Adolfo Suárez, presidente del Gobierno, tenía en la mesa asuntos tan conflictivos como la legalización del Partido Comunista, que, como es bien sabido, se llevó a cabo el 9 de abril de ese mismo año. Por ello, la clave de todo el problema debía ser la discreción y el intento de llegar a un cierto consenso con el poder político, algo que facilitó la victoria de la UCD el 15 de junio de 1977.

A tal efecto, la Comisión Permanente del Episcopado se reunió los días 31 de enero y 1 y 2 de febrero de 1977, utilizando como asesores a Juan José García Failde, Decano del Tribunal de la Rota de la Nunciatura de Madrid, y al jesuita José María Díaz Moreno, profesor de la Universidad Pontificia de Comillas, así como a José Martínez de Lahidalga, profesor de la Facultad de Teología de Vitoria (éste último no estuvo presente pero envió un informe en el que hacia público su criterio). Con la participación de tres hombres partidarios de no obstaculizar la ley del divorcio, la jerarquía dejaba claras sus intenciones, aunque no supiera exactamente cómo definirlas o concretarlas. El choque entre el Derecho Natural y el Evangelio, por un lado, y la realidad política, por otro, provocaba un brutal conflicto ideológico entre los obispos, que realmente no encontraban la forma de resolver la situación. Por ello decidieron pasar el problema a la Comisión Episcopal para la Doctrina de la $\mathrm{Fe}^{8}$, aunque da la impresión de que no poseian un criterio propio sino que se encontraban mediatizados por la opinión de los líderes de la Conferencia Episcopal. De hecho, el resultado de su deliberación fue una puerta abierta a un posible «sí» a la ley del divorcio.

Lo que realmente hacía la Comisión Episcopal para la Doctrina de la Fe era dejar todo en manos de la autoridad política. Tras recordar eviden-

8 Ésta se encontraba presidida por un hombre secundario de la jerarquia, Miguel Roca Cabanellas, y era de carácter un tanto indefinido, pues alternaba los conservadores como Ángel Temiño o Antonio Palenzuela con aperturistas (relativos) como José María Setién o Antonio Briva Mirabent. 
cias como que «el divorcio es de suyo un mal para la sociedad», que «la mera posibilidad legal del divorcio es ya una invitación al mismo", que «este tipo de legislación es prácticamente irreversible» o que «induce a muchos a identificar lo legalmente admitido con lo éticamente líciton, la conclusión a la que se llegaba era la siguiente: «Esto no significa que el legislador esté obligado siempre a categoría de norma legal todo lo que es una exigencia ética, o que deba reprimir con medidas legales todos los males en la sociedad. La tutela de ciertos bienes y la exclusión de males mayores pueden originar un conflicto de valores ante el cual el gobernante ha de poner en juego la prudencia politica en orden al bien común, que si no puede prescindir de los valores éticos, tampoco debe desconocer la fuerza de las realidades sociales" ${ }^{9}$. Es decir, la manera de justificar una hipotética ley del divorcio era en función de si ésta era capaz de originar males mayores que el de la propia ruptura de la unión conyugal.

Este juego de iridefiniciones fue denunciado por, cómo no, José Guerra Campos, concretamente en noviembre de 1977. Guerra se sentía plenamente satisfecho por el caso de Brasil, donde la jerarquía de aquel país se había opuesto con una gran rotundidad pública a la ley del divorcio que el Congreso Nacional del país carioca había aprobado el 23 de junio de 1977. Debido a ello diría a sus fieles diocesanos: «Los Obispos del Brasil con ejemplar unanimidad (muy al contrario de lo que sucedía en España) se opusieron a la ley antes de su aprobación y no dejaron de reprobarla después de ser aprobada, fieles al Evangelio y nada preocupados por ir contra la "opinión» triunfante. Actitud muy conforme a lo que postula de los obispos el Sumo Pontífice. Y que hace destacar más el lamentable espectáculo de ambigüedades, cedimientos y aun complicidad, que se ofrece en España desde tribunas de alta responsabilidad eclesiástica" 10. Parece bastante obvio hacia quién iban dirigidos los ataques.

Los meses siguientes fueron bastante tranquilos para el sector progresista de la jerarquia, hasta que Guerra volvió a romper su silencio con un documento titulado "Ideas claras sobre la ley civil del divorcio" 11. Ciertamente éste hacía justicia a su título, porque la claridad utilizada por el Obispo de Cuenca era realmente meridiana. Podemos resumirla en seis ideas fundamentales: la indisolubilidad del matrimonio y la consiguiente exclusión del divorcio vincular constituyen una parte fundamental de la

9 “La estabilidad del matrimonio", en Ecclesia, núm. 1837, 14 de mayo de 1977, págs. 1115.

10 Boletín Oricial del Obispado de Cuenca, núm. 7, noviembre de 1977, pág. 134.

11 Boletín Oficial del Obispado de Cuenca, núm. 3, marzo-abril de 1978, págs. 108-113. 
Ley de Dios, y ésta es de obligado cumplimiento no sólo para todos los católicos, sino para todos los hombres (1); tal Ley de Dios es expresión del amor del Creador hacia sus «criaturas", por tanto sólo puede ser beneficio para los hombres la indisolubilidad del matrimonio (2); los que defienden una ley civil del divorcio sólo tienen dos razones para postularla, el respeto a la libertad en una sociedad pluralista y la necesidad de evitar malos mayores, con lo cual la idea de pragmatismo se impone sobre la Palabra de Dios (3); la apelación al principio de libertad debe ser cuestionada, porque hay que recordar que el Concilio Vaticano II 12 enseña que la libertad civil tiene que ser limitada por exigencias del bien común (4); en el caso de que fuera justificable una ley del divorcio con el fin de evitar males mayores, habría que ver hasta qué punto esto es cierto, por lo que se conoce de experiencias en otros países y por la propia peculiaridad histórica de España (su larga tradición católica) (5); y la prudencia moral debe imponerse en las situaciones críticas, porque sólo así se conseguirá el mayor bien posible (6).

En ese mismo año 1978 tres voces más del episcopado se alzarían contra lo que comenzaba a parecer como inevitable. El 30 de junio de 1978 el Obispo de Tenerife, Luis Franco, publicaba una «Exhortación pastoral contra el divorcio» 13. Desde el punto de vista doctrinal no aportaba nada llamativo, reiterando los mismos argumento de siempre: la indisolubilidad del matrimonio, el divorcio como elemento que atenta contra la Ley Natural, la imposibilidad de los seres humanos para romper algo que trasciende su propia naturaleza. En parecidos términos se expresaria el Obispo de Tenerife, Ángel Temiño, en su documento «El divorcio y la Constitución» 14 , aunque éste incidiría aún más en la idea de que el divorcio como instrumento para evitar males mayores tenía nulo fundamento (sobre todo porque eran muchos más los casos en los que el divorcio legalizado produciría perjuicios que beneficios), y que, aunque la posibili-

12 Nos permitimos señalar una notable incoherencia por parte del que fue durante nada menos que un cuarto de siglo Obispo de Cuenca. Guerra Campos se vale del Concilio Vaticano II para fortalecer sus argumentos, pero a lo largo de su vida se "olvidón en no pocas ocasiones de lo que éste señalaba. De hecho, ese mismo Concilio había aprobado el 7 de diciembre de 1965 la declaración "Dignitatis humanae", en la cual se apostaba claramente por la separación Iglesia-Estado. Sin embargo, a ello respondió Guerra dos años después aceptando el cargo de procurador en Cortes (que había sido rechazado por el Arzobispo de Barcelona) y votando en contra de la Ley para la Reforma Política en noviembre de 1976 (debido a la cual acabaría perdiendo su puesto en las Cortes). Véase al respecto PIÑOL, J. M.: La transición democrática de la Iglesia católica española. Madrid, Trotta, 1999, pág. 373, y Soto, A.: La transición a la democracia. España, 1975-1982. Madrid, Alianza Editorial, 1998, pág. 42.

13 Boletín Oficial del Obispado de Tenerife, núm. 8, agosto de 1978, págs. 599-613.

14 Boletín Oficial del Obispado de Orense, núms.7-8, julio-agosto de 1978, págs. 315-318. 
dad de divorciarse no obligaba a esto, lo que hacía era incitar al mal, por lo que los católicos no podían aceptar de ninguna manera esta situación. La última censura episcopal contra el divorcio previa a la aprobación de la Constitución procedió de las Islas Baleares y corrió a cargo del Obispo de Ibiza, José Gea Escolano, con una carta titulada «El cristiano ante el divorcio» 15.

Sin embargo, todas estas instrucciones pastorales no hacian sino reflejar el carácter minoritario de la más dura oposición al divorcio dentro del episcopado. Se trataba, además, de diócesis sin particular protagonismo, pues en Madrid-Alcalá, Sevilla, Barcelona o Toledo, por citar las de mayor importancia, el silencio era la pauta de conducta. Y así se mantendría practicamente hasta la aprobación de la ley, con la única excepción de una durísima carta escrita por Marcelo González, el Cardenal Primado de Toledo y el único miembro del clero conservador de auténtica relevancia pública. El partido en el poder, la UCD, una vez que la Constitución fue aprobada en referéndum por los españoles (6 de diciembre de 1978), comenzó a apercibirse de la necesidad de plantearse una ley del divorcio. De hecho, ya en las segundas elecciones democráticas, celebradas en marzo de 1979, el partido de Suárez incluyó su oferta sobre el divorcio ${ }^{16}$, perfectamente informados de la necesidad de ésta para garantizar un triunfo electoral que se acabó consiguiendo pero que ya no se volvería a repetir. Tras la victoria, Adolfo Suárez nombró un nuevo gobierno, recayendo la cartera de Justicia, encargada a la sazón del proyecto divorcista, en el democristiano Iñigo Cavero. Este se puso a trabajar en la nueva ley nada más llegar al ministerio, nombrando una comisión asesora en la cual

15 Boletín Oficial del Obispado de lbiza, núm. 895, mayo de 1978, págs. $43-74$.

16 El programa de la UCD decia lo siguiente: «El ordenamiento civil salvaguardará la estabilidád del matrimonio y la familia. El matrimonio canónico tendrá plenos efectos civiles tal como lo reconoce y reguia el derecho común del Estado.

El principio de la libertad religiosa y el pluralismo democrático proclamados por el Concilio Vaticano Il y por la nueva Constitución española implican que no siempre es posible ser elevado a categoria de norma legal lo que constituye una exigencia ético-religiosa cuya plenitud de efectos debe promoverse y lograrse en el ámbito de esa libertad religiosa garantizada por el Estado.

La ley civil que tutela esa conciencia religiosa no puede, sin embargo, imponer hasta el límite las consecuencias de ese ideal religioso sin discriminar a los ciudadanos.

Los tribunales del Estado tendrán la competencia exclusiva en lo que se refiere a la separación de los cónyuges, a la disolución del vinculo civil y a la posibilidad de reconocer la sentencia de nulidad sacramental siempre que se ajuste al derecho del Estado.

No se admitirá el divorcio por mero acuerdo de los cónyuges. Las causas de separación y disolución a efectos civiles han de ser tasadas y graves para los supuestos en que los matrimonios estén definitivamente rotos y en todo caso se protegerán especialmente los íntereses de los hijos". 
quedaban integrados José Luis Lacruz Berdejo, Manuel Peña, Agustín Luna, Manuel Villar Arregui y Eugenio Nasarre: éste último, un hombre de hondas raíces cristianas, sería el encargado de preparar un primer borrador 17.

Desde los momentos iniciales, Cavero se apercibió de que la principal piedra de toque sería lograr un consenso en el partido, y con esta idea trabajó al máximo. Así, en el propio verano de 1979 presentó al Consejo de Ministros un informe titulado "La reforma del régimen matrimonial del Código Civil y la regulación legal del divorcio", siendo la acogida general bastante favorable. Al mismo tiempo, incorporó al equipo diseñado para la preparación de la ley a toda una serie de políticos de la UCD con muy diversos posicionamientos ideológicos: José Luis Meilán (hombre próximo al Opus Dei) ${ }^{18}$, Javier Moscoso (socialdemócrata, acabaría pasándose al PSOE, con el que llegaría a ministro), María Dolores Pelayo (de igual ideología y devenir que Moscoso, aunque sin llegar a ministra), José Luis Ruiz Navarro (miembro de la Democracia Cristiana),... El encargado de la ponencia sería el notario José Antonio Escartín.

Posiblemente dentro de la jerarquía el hombre menos contrario a una ley del divorcio era Narcís Jubany ${ }^{19}$, un clérigo de gran prestigio en el seno de la Iglesia catalana. En cualquier caso, Cavero y Nasarre hablaron

17 Sin embargo, el té́logo Enrique Miret Magdalena asegura que el proyecto de divorcio había sido redactado por Juan Antonio Ortega Díaz-Ambrona, letrado del Consejo de Estado y en aquel momento subsecretario del ministerio de Justicia con Landelino Lavilla como encargado del ramo. Esto es perfectamente posible, porque Ortega añadia, a su brillante preparación juridica, el hecho de ser uno de los líderes más destacados de la corriente democristiana. Véase al respecto Miret Magdalena, E.: Luces y sombras de una larga vida. Memorias. Barcelona, Planeta, 2000, pág. 435.

18 Jesús Ynfante asegura que dentro de la UCD había dos docenas de diputados que giraban en mayor o menor medida en torno al Opus Dei. Dentro de ellos había aproximadamente una decena especialmente vinculada, entre los cuales cita a Meilán. YNFanTE, J.: Opus Dei. Asi en la tierra como en el cielo. Barcelona, Grijalbo, 1996, pág. 410.

19 Jubany era uno de los miembros más progresistas de la jerarquía española y su postura era, posiblemente, la menos proclive a evitar el proyecto divorcista. De hecho, el 21 de junio de 1979 había pronunciado una conferencia en el Club Siglo XXI donde dijo lo siguiente: «EI legislador no está obligado a elevar a categoría de norma legal todo lo que es exigencia ética (y), por otra parte, es evidente que no todas las leyes civiles de divorcio que existen en el mundo son iguales ni merecen el mismo enjuiciamiento, (si se produce) un conflicto de valores, el gobernante ha de poner en juego la prudencia política en orden al bien común, que, si no puede prescindir de los valores éticos, tampoco puede desconocer la fuerza de las realidades sociales". JUBANY, N.: "Neutralidad política de la Iglesia: fundamentos y consecuencias", en Club Siglo XXI: Perspectivas de una España democrática y constitucionalizada. Madrid, Unión Editorial, 1979, 3 vols., vol. III, pág. 506. No obstante, declararía tres años después a la periodista Maria Mérida 
con varios miembros con el objetivo de lograr un apoyo con base real $y$, según Abel Hernández ${ }^{20}$, utilizaron siempre el mismo argumento para que la Iglesia no tratara de obstaculizar el proceso: siempre será mejor una reforma de la situación con la moderación de la UCD por medio, que dejar un vacio legal que pueda ser cubierto de una manera más radical por otros partidos (se entiende que de izquierdas). Sin embargo, organizaciones tan poderosas consideraron que la proposición de ley debía proceder precisamente de los no cristianos, $y$, que mientras éstos no estuvieran en el poder, nada se debía hacer para facilitar el divorcio.

Al tiempo que este debate comenzaba a coger fuerza, Iñigo Cavero y Eugenio Nasarre viajaron a Roma con el objetivo de entrevistarse con Casaroli, Secretario de Estado del Vaticano, Silvestrini, Presidente del Consejo de Asuntos Públicos de la Iglesia, y el riojano Eduardo Martínez Somalo, sustituto de la Secretaría de Estado. Mientras Casaroli, un hombre conservador que mantenía muy buenas relaciones con el Opus Dei (en especial con López Rodó cuando éste era ministro de Asuntos Exteriores), mostraba una posición más inflexible, Silvestrini se abrió a la oferta del gobierno español pues sabía que la batalla contra el divorcio mantenida en Italia había constituido un gran error y que, en cualquier caso, debía evitarse una división en el seno de la sociedad española. A partir de este momento, Cavero supo que la Iglesia, al mismo tiempo que mantendría inamovible su doctrina de la indisolubilidad del matrimonio, no se enfrentaría con el gobierno en su proyecto de regular civilmente el divorcio 21 . Era una manera más de reafirmar la separación Iglesia-Estado consumada por la Constitución de 1978 y los

que "el divorcio no es ni puede ser un derecho de la persona humana, como si aquel que hizo el matrimonio, marido y mujer, fuera absolutamente libre para deshacerlo y se tratara de un contrato cualquiera". MÉridA, M.: Entrevista con la Iglesia. Barcelona, Planeta, 1982, pág. 128. Jubany representaría, así pues, el sector de la jerarquia consciente de lo perjudicial del divorcio para la sociedad (así como la imposibilidad doctrinal para defenderlo) pero, al mismo tiempo, de la incapacidad de la Iglesia para impedir su aprobación como consecuencia de la separación IglesiaEstado. Si Juan Carlos I, como Jefe de Estado, no podia intervenir en las designaciones de las sedes episcopales, con la misma razón ni Vicente Enrique y Tarancón ni Díaz Merchán (los dos presidentes de la Conferencia Episcopal a lo largo de todo el recorrido legal del divorcio) podian impedir que el Gobierno aprobara una ley civil del divorcio.

20 Hernández, A.: El Quinto Poder. La Iglesia de Franco a Felipe. Madrid, Temas de Hoy, 1995, págs. 145 y 146.

21 A pesar de ello, la Iglesia no podia renunciar a hacer pública su opinión, algo que hizo durante la celebración de la XXXII Asamblea Plenaria de la Conferencia Episcopal. El Comité Ejecutivo, compuesto en su casi totalidad por obispos progresistas (Enrique y Tarancón, Díaz Merchán, Cirarda, González Moralejo y Marti Alanis) y donde el único miembro netamente conservador era Marcelo González, ya había tratado el asunto del divorcio el 6 de septiembre, y la 
acuerdos parciales de 197922 . El silencio entre el episcopado se impuso, siendo roto sólo por la solitaria voz del Obispo de Cuenca, único prelado que denunció abiertamente la connivencia de la jerarquía con el proyecto de Iñigo Cavero ${ }^{23}$.

discusión la habia continuado la Comisión Permanente (de igual signo progresista) los dias 25 al 27 de septiembre. Pero el tema, sin embargo, no tuvo una definitiva concreción hasta la Asamblea Plenaria de los días 19 al 24 de noviembre de 1979, de donde salió la primera y clara instrucción sobre el divorcio. En efecto, el 23 de noviembre de 1979 se hacía pública la «Instrucción colectiva del Episcopado Español sobre el divorcio civil", donde se decia: «No podemos admitir que la regulación civil del divorcio sea un derecho de la persona humana. No se trata de reconocer un derecho, sino, a lo más, de ofrecer un supuesto remedio a un mal social. (...) Consideramos que es absolutamente inaceptable el liamado divorcio consensual. Una ley que introdujese el divorcio de tal manera que la pervivencia del vínculo quedase a disposición del cónyuge, sería rechazable moralmente y no podría ser aceptada por ningún católico, ni gobernante ni gobernado (...) En todo caso sepan los católicos que el hipotético divorcio civil no disolvería su vínculo matrimonial y que la doctrina de la Iglesia permanece inmutable. Sean conscientes de que aquí se les ofrece una ocasión de demostrar la fidelidad a Jesucristo (generosa siempre y a veces muy sacrificada), asi como de dar un testimonio ejemplar a todos nuestros hermanos y una contribución importante al bien común de la sociedad». Sin embargo, en hecho histórico por lo novedoso de lo mismo, la Iglesia recordaba a sus fieles que, en cualquier caso, su capacidad de exigencia al Estado se encontraba limitada por la propia Constitución de 1978. Por ello, dirían: «Respetemos la justa autonomía de la autoridad civil a la que corresponde legislar atendiendo a las exigencias del bien común compuesto por diversos elementos". Ecclesia, núm. 1960, 1 de diciembre de 1979, págs. 20 y 21.

22 Realmente, la posición de la jerarquía católica española era francamente difícil. Porque el propio Papa Juan Pablo II se habia opuesto abiertamente el divorcio en una famosa homilia pronunciada en Limerick (Irlanda) el 1 de octubre de 1979, en lo que parecía un intento por parte de la Santa Sede de evitar el divorcio en dos naciones que todavía no tenían una ley civil y que se distinguian por su larga tradición católica (Irlanda y España). Las palabras de Juan Pablo II no podian haber sido más claras: “Ojalá continúe siempre Irlanda dando testimonio ante el mundo moderno de su tradicional empeño por la santidad e indisolubilidad del vínculo matrimonial. Ojalá los irlandeses mantengan siempre el matrimonio a través de un compromiso personal y de una positiva acción social y legalm. Juan Pablo II, heraldo de paz. Madrid, BAC, 1979, pág. 150. El problema para los obispos españoles es que estaban a punto de consumarse los acuerdos parciales de 1979, que finalizaban la separación entre la Iglesia y el Estado iniciada con la renuncia del Rey al privilegio de presentación de 1976 e impulsada de una manera definitiva con la Carta Magna de 1978.

23 Boletín Oficial del Obispado de Cuenca, núm. 12, diciembre de 1979, págs. 264 y 265. Diría: «el Papa Pablo VI declaró lamentable que los católicos no hubiesen votado todos contra el divorcio en Italia, según lo exigía la coherencia con su condición de católicos (1974). Si recordamos que Juan Pablo II acaba de exhortar a que persevere en su actitud actual una nación, Irlanda, que, como España, no tiene legislación divorcista (octubre 1979). Si recordamos que los Obispos del Brasil protestaron en 1977 con nitidez evangélica contra la decisión del Congreso de introducir un divorcio más restringido que el que se proyecta en España. ¿Realmente España es tan diversa y su pluralismo tan singular como para declarar lícito en ella lo que en las naciones citadas se ha declarado pernicioso?" 
Podemos afirmar sin temor a equivocarnos que la Iglesia actuó con un inusual progresismo, porque la propia doctrina pontifica le apoyaba firmemente para haber hecho una dura labor de obstrucción del divorcio civil: tanto León XIII en $1880^{24}$, como Pío XI en 1930 25, Pío XII en $19422^{26}$, Juan XXIII en 1961 27, Pablo VI en 1970 28, Juan Pablo I en 197829 y

24 «El divorcio es el enemigo número uno de la prosperidad de las familias y del Estado, porque el divorcio nace cuando la moral de los pueblos ha quedado corrompida y, como enseña la experiencia, deja el camino expedito y la puerta abierta a las costumbres más viciosas en la vida pública y privada. Y mucho más claramente se verá la gravedad de estos males si se considera que no hay freno tan poderoso que, una vez concedida la facultad del divorcio, pueda contenerla, pueda contenerla dentro de ciertos límites...». Encíclica "Arcanum divinae», en La Familia. Madrid, 1975, pág. 68.

25 «Que si el hombre llegara injustamente a separar lo que Dios ha unido, su acción sería completamente nula, pudiéndose aplicar, en consecuencia, lo que el mismo jesucristo aseveró con estas palabras: "Cualquiera que repudia a su mujer y se casa con otra, adultera; y el que se casa con la repudiada del marido, adultera" (LC. 16, 18). Y estas palabras de Cristo se refieren a cualquier matrimonio, aun al solamente natural y legítimo, pues es propiedad de todo verdadero matrimonio la indisolubilidad, en virtud de la cual, la solución del vínculo queda sustraída al beneplácito de las partes y a toda potestad secular". Encíclica "Casti Connubii", en Colección de Enciclicas y Documentos Pontificios. Madrid, Acción Católica, 1967, pág. 1629.

26 "En la unidad del vínculo conyugal ved impreso el sello de la indisolubilidad. Es, ciertamente, un vínculo al cual inclina la naturaleza, pero que no está causado necesariamente por los principios de la naturaleza, sino que se realiza mediante el libre albedrí; pero si la simple voluntad de los creyentes lo puede contraer, no lo puede desatar. Esto se dice no solamente de las nupcias cristianas, sino en general de todo matrimonio válido que se haya contraido sobre la tierra con el mutuo consentimiento de los cónyuges". Discurso pronunciado a los recién casados el 22 de abril de 1942, publicado en Ecclesia, núm. 49, 20 de junio de 1942, pág. 17.

27 «En esta materia hacemos una grave declaración: la vida humana se comunica y propaga por medio de la familia, la cual se funda en el matrimonio uno e indisoluble". Encíclica "Mater et Magistra", en Ocho grandes mensajes. Madrid, BAC, 1972, pág. 182.

28 "La Iglesia, en efecto, no puede dejar de proclamar el altísimo principio que, inscrito ya en el derecho natural, ha sido confirmado y reforzado para los cristianos por la Ley del Evangelio, donde Cristo advierte que el hombre no puede atreverse a separar lo que Dios mismo ha unidon. Pablo VI: Enseñanzas al Pueblo de Dios. Madrid, BAC, 1970, pág. 456. El Concilio Vaticano ll se habia encargado de apuntalar la doctrina de Pablo VI al afirmar lo siguiente: «Fundada por el Creador y en posesión de sus propias leyes, la íntima comunidad conyugal de vida y amor se establece, sobre la alianza de los cónyuges, es decir, sobre su consentimiento personal e irrevocable. Asi, del acto humano por el cual los esposos se dan y se reciben mutuamente, nace, aun ante la sociedad, una institución confirmada por la Ley Divina. Este vínculo sagrado, en atención al bien, tanto de los esposos y de la prole como de la sociedad, no depende de la decisión humana...» “Esta última unión como mutua entrega de dos personas, lo mismo que el bien de los hijos, exigen plena fidelidad conyugal y urgen su indisoluble unidad". Ocho grandes mensajes, op. cit., pág. 436.

29 «Particularmente importante es la indisolubilidad del matrimonio cristiano: aunque es una parte difícil de nuestro mensaje, debemos proclamarla plenamente como parte de la palabra de Dios, parte del misterio de la fe. Pero, al mismo tiempo, estamos junto a nuestro pueblo en sus problemas y dificultades. Deben saber ellos siempre que los amamos". L'Osservatore Romano, edición semanal en lengua española, 22 de septiembre de 1978. pág. 6. 
Juan Pablo II en $1980^{30}$, habían mostrado su más abierta oposición hacia la disolución de un vínculo, el conyugal, que se fundamentaba en la indisolubilidad. No lo hacian basándose en nada, sino en la piedra fundamental de la Iglesia católica y más aún del cristianismo: las Sagradas Escrituras. Porque tanto el Antiguo Testamento 31 como el Nuevo Testamento 32 constituian y siguen constituyendo la base documental e incuestionable para todos aquellos que defienden la imposibilidad de la ruptura del vínculo conyugal.

Sin embargo, el gobierno seguía con sus proyectos adelante. Buscando que no hubiera confrontación con los acuerdos parciales entre la Iglesia y el Estado, el proyecto fue incluido dentro de la reforma del título octavo del Código Civil y se remitió al Consejo de Ministros en enero de 1980. Aquí sí se produjo un cambio con respecto a la primera vez que se presentó el proyecto: mientras en la anterior, como hemos señalado anteriormente, la unanimidad entre los distintos miembros del gabinete fue bastante notoria, ahora sí hubo un enfrentamiento, entre la posición más aperturista de Luis González Seara (ministro de Universidades) y la más conservadora de Antonio Fontán (ministro de Administraciones Territoriales y, al mismo tiempo, miembro del Opus Dei). No obstante, la confrontación fue superada y el día 18 de febrero ${ }^{33}$ el proyecto era aprobado por el gobierno.

30 «Los cristianos deben dar testimonio abierto y convencido de que en Cristo se encuentra la salvación del hombre, deben actuar contra los peligros que profanan el santuario de la familia y amenazan con devastar sus sagradas estructuras; quiero decir el hedonismo que lleva a la falta de amor entre los cónyuges y hacia los hijos, a la infidelidad conyugal, al divorcio y al aborto". Ya, 2 de septiembre de 1980, pág. 15.

31 «Entonces Yavé Dios hizo caer sobre el Hombre un sueño letárgico, y mientras dormía tomó una de sus costillas, reponiendo carne en su lugar; seguidamente de la costilla tomada al hombre formó Yavé Dios a la mujer y se la presentó al Hombre, quien exclamó: «Esta sí que es hueso de mis huesos y carne de mi carne, ésta será llamada varona, porque del varón ha sido tomada." Este es el por qué el hombre deja a su padre y a su madre y se une a su mujer, y son los dos una sola carne" (Libro del Génesis 21-24). La Santa Biblia. Zaya (Vizcaya), Ediciones Paulinas, 1972, pág. 11.

32 "Se acercaron unos fariseos preguntándole, con la intención de tentarle, si es lícito al marido repudiar a su mujer. Pero Jesús les respondió: “¿Qué os mandó Moisés?" Ellos dijeron: "Moisés mandó escribir un acta de divorcio y despedirla". Jesús les dijo entonces: «Moisés escribió este precepto por la dureza de vuestros corazones. Pero al principio de la creación Dios los hizo macho y hembra. El hombre dejará, pues, a su padre y a su madre, y serán los dos una sola carne. Pues bien, lo que Dios ha unido, no debe separarlo el hombre". Ya en casa, de nuevo los discípulos le preguntaron acerca de esto; y Jesús les dijo: "Quien se divorcie de su mujer y se case con otra, comete adulterio contra la primera; y si la mujer se divorcia de su marido, y se casa con otro, adultera" (Evangelio según San Marcos 10, 2-12). La Santa Biblia, op. cit., pág. 1198.

33 Sólo ocho días antes, el 10 de febrero de 1980, Laureano Castán, Obispo de SigüenzaGuadalajara, había publicado el documento "La indisolubilidad del matrimonio y el derecho na- 
El proyecto de Cavero era, efectivamente, una síntesis perfecta entre la posibilidad del divorcio y la dificultad para obtener el mismo. Especialmente importante era el artículo 87, el cual decía que, de manera excepcional, el Juez podía denegar el divorcio cuando se probara que ocasionaba a los hijos o al otro cónyuge perjuicios de especial gravedad, a los que debería referirse la sentencia. De esta manera podía romperse la opción del mutuo acuerdo entre los cónyuges para obtener el divorcio, introduciéndose una tercera parte de carácter decisorio. En lo que se refería a la separación, se observaban las siguientes causas para la misma: el abandono justificado del hogar, las relaciones sexuales extraconyugales, la conducta injuriosa o cualquier otra violación grave de los deberes conyugales, dejándose claro que no se podian utilizar las relaciones sexuales extraconyugales si existía previa separación de hecho libremente consentido por ambos o impuesta por el demandante (1); cualquier violación grave de los deberes respecto de los hijos comunes (2); la condena a pena de privación de libertad por tiempo superior a seis años (3); y el alcoholismo, la toxicomanía o las perturbaciones mentales, siempre que el interés de la farnilia exigiera la suspensión de la convivencia y no pudiera esperarse razonablemente su restablecimiento (4). Por último, en lo que concernía a las causas de divorcio, llamaba la atención la longitud de los plazos: en algunos casos, se llegaba a exigir el cese efectivo de la convivencia conyugal durante, al menos, cuatro años ininterrumpidos ${ }^{34}$.

Precisamente por hechos como este último la izquierda aprovechó para hacer pública sus más duras críticas, especialmente por medio de las páginas de El País y Mundo Obrero. No gustaba singularmente el hecho de que los cónyuges no pudieran divorciarse por mero acuerdo, sino

tural’. Éste destacaba por su enorme dureza y posiblemente en él se contienen las acusaciones más condenatorias contra todo lo que rodeaba el divorcio. Castán afirmaría que éste era tan antinatural como introducir la poligamia de mujeres y que de él se derivarian males gravísimos, porque favorece el egoísmo, la infidelidad, la discordia: llegará a decir que de los matrimonios rotos salen huérfanos con padre y madre, suicidas, locos, delincuentes y prostitutas. Hay que decir que Castán era, posiblemente junto con Guerra Campos, el obispo más consèrvador de la jerarquia católica, algo que seguramente puede vincularse al hecho de que sus primeros años como sacerdote fueron precisamente los más duros de la persecución religiosa en España, aquellos que llevaron a la tumba a nada menos que unos siete mil religiosos (hablamos, obviamente, de la Guerra Civil). Desconocemos si lo hizo diciendo la verdad o porque sencillamente no aguantaba ser obispo en un Estado aconfesional, pero lo cierto es que Castán presentó su renuncia (que fue aceptada unos meses después) como prelado a la Santa Sede ya en 1980 (adujo siete dolencias distintas), cuando en realidad le quedaba todavía varios años hasta su jubilación definitiva (contaba en aquel momento con sólo sesenta y ocho años). Ver Ecclesia, núm. 1992, 2 de agosto de 1980, pág. 20.

34 Boletín Oficial de las Cortes Generales. 13 de marzo de 1980, págs. 855-867. 
que las causas de separación tuvieran que ser tasadas y graves para los supuestos en que los matrimonios estuvieran definitivamente rotos, buscándose por encima de todo la protección de los hijos. A punto de ingresar el proyecto en la cámara baja, las tensiones aumentaron y los hombres vinculados al Opus Dei, particularmente el diputado Díez Piniés, presentaron batalla a través de una enmienda de sustitución (que vendría acompañada por otras tres personas no vinculadas al Opus Dei). Además, si la UCD, en su mayoría era poco favorable al proyecto divorcista, menos respaldo iba a encontrar aún en la derecha, pues uno de los diputados más importantes de Alianza Popular, Gregorio López Bravo, era también miembro del Opus Dei y, de hecho, mantendría fuertes discusiones con el propio Cavero ${ }^{35}$.

Sin embargo, lo que dio un giro más sustancial a la situación no fue el conflicto generado en torno al divorcio, sino una de las grandes crisis políticas de los últimos años de la UCD. Entre el 7 y el 9 de julio de 1980 se producen las llamadas reuniones de «la casa de la pradera», que, fuera de denominaciones más o menos humorísticas, son celebradas en una finca que el Canal de Isabel II tenía cerca de Madrid: tales reuniones constituyen una auténtica rebelión contra la figura de Suárez, que, como recuerda Álvaro Soto, a partir de entonces ha de abandonar su estrategia de control absoluto (reconocido por el I congreso del partido en función de los exitosos resultados electorales) para recurrir a la fórmula asociativa, es decir, aquella en que las decisiones se regían por pactos entre las distintas familias ideológicas de la UCD ${ }^{36}$.

En función de ello, Francisco Fernández Ordóñez, principal representante de la familia socialdemócrata, solicitó (aunque sería más correcto decir que exigió) a Suárez en el nuevo gobierno nombrado en septiembre de 1980 (y que sería el último del que fuera primer presidente de la democracia) la cartera de Exteriores o de Justicia: dado que para el palacio de Santa Cruz ya estaba elegido José Pedro Pérez Llorca, Fernández Ordóñez fue a parar a Justicia, desplazando a Cavero, a partir de entonces al frente de Cultura. Cavero ya le había explicado a Suárez el peligro que entrañaba dejar en manos de un socialdemócrata el proyecto divorcista, pero el presidente del Gobierno se encontraba atado de pies y manos desde el verano y no pudo hacer nada por evitarlo ${ }^{37}$. El político demo-

35 HeRnández, A., op. cit., pág. 147.

36 Sото, A., op. cit., págs. 90 y 91.

37 A pesar de que es cierto que Suárez dio varios giros a la izquierda a lo largo de sus casi cinco años de presidente del Gobierno (y por los cuales cayeron dos fieles suyos como Alfonso 
cristiano sabía bien lo que decía, entre otras cosas porque Fernández Ordóñez habia publicado un libro ${ }^{38}$ poco tiempo antes donde se mostraba partidario del divorcio e, incluso, del aborto.

Lo primero que hizo Fernández Ordóñez al llegar al ministerio de Justicia fue encontrarse con una dura instrucción pastoral ${ }^{39}$ de Marcelo González, Cardenal Primado de Toledo, en contra del proyecto divorcista. Se trataba de un extenso documento, bastante bien salvaguardado doctrinalmente, donde se afirmaba la autonomía relativa del Estado y la capacidad de la Iglesia para predicar la fe con total libertad y dar su juicio moral en cuestiones incluso concernientes a la política. En otras palabras, Marcelo González venía a recordar que, aunque la Iglesia no tenía potestad jurídica para impedir una ley del divorcio, sí se encontraba plenamente capacitada para manifestar cualquier opinión. Más aún, la Iglesia, en cuanto mera confesión religiosa, poseía el derecho de «manifestar libremente el valor peculiar de su doctrina para la ordenación de la sociedad y para la vitalización de toda actividad humana» 40 . De hecho, González se encontraba tan seguro a la hora de hacer sus reivindicaciones que llegaria a afirmar lo siguiente: "La gravedad y la irreversibilidad del paso legislativo que va a dar el Estado español al admitir el principio de disolubilidad extrínseca de todo matrimonio, a efectos civiles, lo consideramos de tal trascendencia que el silencio anuente, o la tolerancia pasiva o la mera apariencia de aceptación por parte de la Iglesia, y mucho más las palabras que pueden servir de aliento a tal legislación arrojarían una oscura duda de sombra sobre la credibilidad de todo su Magisterio en el orden socio-político y gravaría con enorme responsabilidad su actuación ante'el juicio de la historia, y nos atreveriamos a afirmar ante Dios, señor de la Historia y de todos los hombres" 41. El Cardenal Primado consideraba que no sólo estaba en juego la conciencia personal de los cónyuges, sino

Osorio, primero, y Fernando Abril Martorell, después), el político abulense era y ha seguido siendo un hombre de firmes convicciones religiosas y practicante de un catolicismo conservador, por lo que parece dificil que tuviera especial interés en un proyecto divorcista muy progresista. Además, su mujer, Amparo Illana, supernumeraria del Opus Dei y elemento de posiblemente gran influencia sobre Suárez, era una gran enemiga del divorcio, y, de hecho, no soportaba estar al lado de personas que hubieran roto su vinculo conyugal. Al menos asi lo asegura Gregorio Morán en su libro Adolfo Suárez. Historia de una ambición. Barcelona, Planeta, 1979, pág. 352.

38 Hablamos de La España necesaria. Madrid, Taurus, 1980, págs. 231 y 232.

39 Veáse al respecto la instrucción pastoral titulada "Divorcio, doctrina católica y modernidad", en Boletín Oficial del Arzobispado de Toledo, nos.9 y10, septiembre-octubre de 1980 , págs. 419-447.

40 Declaración «Dignitatis Humanae", en Concilio Vaticano II. Constituciones. Decretos. Declaraciones. Documentos pontificios complementarios. Madrid, BAC, 1966, pág. 690.

41 «Divorcio, doctrina católica y modernidad", op. cit., pág. 431. 
también la institución de la familia, según las exigencias de la Ley Natural y del Bien Común. La solución a la crisis matrimonial no debía ser en ningún caso la ruptura de la unión conyugal: antes al contrario, debía pensarse en fortalecer la vida espiritual y cristiana en las familias (1) y en seguir exponiendo la doctrina católica con toda exactitud con el fin de formar bien las conciencias humanas (2). Además, el Estado español debia olvidar el hecho de que el divorcio estuviera ya introducido en muchos países; en este sentido, "Don Marcelo" (como era conocido en medios eclesiásticos) no tuvo problema en recordar a Fernández Ordóñez que la mayor parte de los votantes de la UCD eran contrarios a la existencia del divorcio ${ }^{42}$. Como si la carta de Don Marcelo hubiera animado la reacción, en aquellos meses finales de 1980 los obispos de lbiza, Orense y Orihuela-Alicante dieron nuevas consignas a sus fieles diocesanos, reiterándose en las ideas que ya habían manifestado en los años inmediatamente precedentes ${ }^{43}$.

Sin embargo, el conjunto de la jerarquía decidió mantenerse a la expectativa, temiendo que se acabaran confirmando los peores presagios: para ellos, de momento el único proyecto que había era el de Cavero, y con el compromiso de que éste fuera el que finalmente se aprobara habian pactado no oponerse frontalmente al divorcio. Precisamente por ello en las seis reuniones que los órganos de la Conferencia Episcopal celebraron desde el 16 de septiembre al 11 de diciembre de 1980 (los tres meses en los que el proyecto estuvo sometido a discusión en la Comisión de Justicia) no se emitió ningún documento novedoso en lo referido a la cuestión divorcista. Las declaraciones al diario católico Ya de José Delicado Baeza, presidente en aquel momento de la Provincia Eclesiástica de Valladolid, constituyen una perfecta muestra de cuál era la consigna

42 Ibídem, pág. 437. "Quiera Dios también que los legisladores españoles se den cuenta de la gravedad del problema, nunca minimizable por el hecho de que el divorcio esté introducido en tantos paises. Que escuche cada uno la voz de su conciencia rectamente formada, para que con su acción sepan servir al verdadero bien común de la familia y la sociedad española, evitando o reduciendo, cuanto les sea posible, el daño que, quizá sin quererlo, podrian causar a muchos, entre los cuales pueden estar los mismos que les dieron su voto. Piensen que algún día han de dar cuenta a Dios de todos sus actos".

43 Véase al respecto Boletín Oficial del Obispado de Ibiza, núm. 921, octubre de 1980, págs. 59-61; Boletín Oficial del Obispado de Orense, núm. 11, noviembre de 1980, págs. 273-280; y Boletín Oficial del Obispado de Orihuela-Alicante, núm. 144, noviembre de 1980, págs. 3-12. No podemos incluir en el mismo grupo a Miguel Ángel Araújo, Obispo de Mondoñedo-El Ferrol, cuya discreta frase ("Nuestro humilde parecer es que hoy, en España, una ley del divorcio no es un mal menor, sino más bien un mal mayor") resume la prudencia con la que actuaban la mayor parte de los prelados españoles. Boletín Oficial del Obispado de Mondoñedo-El Ferrol, núm. 12, diciembre de 1980, págs. 599-601. 
impuesta desde lo más alto de la Conferencia Episcopal: a su parecer, los obispos no deben juzgar si una futurible ley del divorcio es un mal mayor o menor, porque es más adecuado dejarlo «a la autonomía de la autoridad civil» 44.

Lo cierto es que los peores presagios comenzaron a cumplirse. Fernández Ordóñez, con la inestimable ayuda de Enrique Linde (su subsecretario), hombre procedente del PSP, rehizo totalmente el proyecto divorcista. El objetivo fundamental parecía claro: hacer realmente factible la ruptura de la unión conyugal si un matrimonio fracasado así lo solicitaba. Aunque Fernández Ordóñez se confesaba públicamente católico, es posible observar ciertos rasgos anticlericales en sus propias palabras. El nuevo ministro de Justicia considera que el divorcio debía formar parte de una ruptura con el pasado, un pasado en el cual, desde los tiempos del Concilio de Trento, el matrimonio había sido proclamado indisoluble por la legislación española. Tal tradición histórica sólo había sido rota por la república en 1932 a través de la primera ley del divorcio, pero todo ello había quedado en agua de borrajas con la llegada de Franco al poder, quien no sólo enterró el divorcio sino que declaró nulos los divorcios que se habían producido al amparo de la ley de 1932. Fernández Ordóñez recordó el monopolio que la Iglesia había tenido en el tema del matrimonio, ya que la única opción que había era que la institución declarara nulo el matrimonio o, en su defecto, que tramitara la separación. Según el socialdemócrata, los procedimientos ante los tribunales eclesiásticos eran en ocasiones "verdaderas comedias judiciales, en que los cónyuges afirmaban que fueron al matrimonio ignorando su esencia, o que fueron forzados por los padres, o alegando vicios de forma... Todo esto se sabe de sobra» 45 .

Realizando un análisis detenido sobre el proyecto modificado ${ }^{46}$, hay elementos que muestran claramente la fuerte impronta progresista de Fernández Ordóñez. En primer lugar, en lo que se referia al cese efectivo

44 Ya, 18 de diciembre de 1980, pág. 23.

45 Fernández Ordóñez, F.: Palabras en libertad. Barcelona, Argós Vergara, 1982, págs. 75 y 76. El exministro de Justicia recordará las denuncias realizadas por el Cardenal Felici en torno a algunos escándalos de corrupción sucedidos que tenian por protagonistas a los tribunales eclesiásticos. Asegura igualmente que Felici le había dicho que en los últimos diez años (es decir, a lo largo de la ḋ́cada de los setenta) el número de nulidades eclesiásticas había crecido un cinco mil por ciento. Sin embargo, como ya demostraremos más adelante, tales expectativas no se confirmaron de ninguna manera.

46 Éste se encuentra publicado en el Boletín Cficial de las Cortes Generales. Congreso de los Diputados. 30 de diciembre de 1980, págs. 868/23-868/38. 
de la convivencia conyugal (como causa del divorcio), se reducía a un año (antes eran dos) el plazo desde la interposición de la demanda de separación, y también se producía una reducción del plazo de la separación de hecho, pasándose de cuatro años a dos; además, el simple cese efectivo de la convivencia durante dos años daba derecho al divorcio, a petición de uno sólo de los cónyuges, aunque cumpliéndose alguna condición (el que la separación hubiera sido consentida por ambos, el que hubiera resolución judicial firme o declaración de ausencia legal de un cónyuge, o el que se hubiera acreditado que el otro estaba incurso en causa de separación). En segundo lugar, la separación se concedia a petición de uno por causa legal en el otro: en el caso de que no hubiera la citada causa legal, tendría que ser por simple petición de ambos, o de uno consintiendo el otro, una vez transcurrido el primer año de matrimonio. Aquí había una significativa diferencia con el proyecto Cavero, que había establecido en su articulo 81 como conditio sine qua non el que «existiera quiebra profunda y dificilmente superable de la convivencia conyugal» 47. En tercer lugar, se convertía en causa legal para exigir la separación el cese efectivo de la convivencia durante seis meses, libremente consentido: se entendía «libremente consentido» sólo cuando el cónyuge que podía pedir separación por causas legales en el otro no lo hubiera pedido o, al menos, las medidas provisional previstas en el Código. Con lo que, por mera omisión de medidas por parte del inocente durante unos meses, el culpable podía decidir de manera unilateral la separación y, por consiguiente, el divorcio. En resumen, las principales novedades eran la reducción de los plazos, la ampliación del campo de las decisiones por mutuo consentimiento sin comprobación de las causas, la introducción de una forma equivalente al divorcio por decisión unilateral y la restricción de la facultad decisoria del juez.

El vuelco que la situación había dado obligó al Nuncio, Innocenti, a tomar cartas en el asunto ${ }^{48}$. Por ello se entrevistó con el propio Fernández Ordóñez (27 de enero), siendo bastante tensa la conversación. El único testimonio de lo que allí se dijo lo conocemos a través del político socialdemócrata. Según éste, quien recuerda que, además de los dos, también estaba presente Luis Apostúa, Director General para Asuntos Religiosos, el Nuncio manifestó su más abierta oposición al nuevo texto. Tras recor-

47 Boletín Oficial, 13 de marzo de 1980, op. cit., pág. 861.

48 Antonio Innocenti había llegado a España en calidad de Nuncio el 10 de enero de 1981 y su llegada puede decirse que no recibió especialmente buena acogida en determinados medios progresistas, sólo porque Innocenti, al requerimiento de los periodistas que acudieron al aeropuerto, recordó la doctrina de la Iglesia contraria al divorcio. 
darle Fernández Ordóñez que en un pais como Francia, de larga tradición católica, existía una ley del divorcio con doscientos años de vigencia, Innocenti, seguramente recordando tiempos pasados no tan lejanos (aquellos en los que España se proclamaba confesionalmente católica), le respondió que España no era Francia. La contrarréplica de Fernández Ordóñez no pudo ser más dura: España no era una «república bananera». De allí no salió nada positivo e Innocenti sólo pudo marcharse con la certeza de que el ministro de Justicia llevaría adelante su proyecto 49.

También reaccionó la Conferencia Episcopal, que podemos suponer que se sentía traicionada por el Gobierno después de haber obstaculizado lo mínimo posible el proceso legal. El 15 de enero de 1981 se reunió el Comité Ejecutivo de la Conferencia Episcopal, acordándose convocar a la Comisión Permanente a una reunión extraordinaria y urgente para deliberar sobre el nuevo proyecto de ley, que se celebraría finalmente el 24 de enero. Por estas mismas fechas, Luis Gutiérrez Martín, vicario judicial del Arzobispado de Madrid-Alcalá, publicó un duro artículo en Ya donde aseguraba que Fernández Ordóñez estaba atacando las enseñanzas del Episcopado español al haber hecho posible la introducción del divorcio consensual. Recordaba que, ciertamente, España era una sociedad plural, pero que en ella había mayoritariamente una defensa del humanismo cristiano, por lo que lamentaba el daño que se infringía a la institución familiar y el haber convertido al juez en mero fedatario del cumplimiento de las condiciones formales de la ley. Para él, se había dado paso al ideal marxista, partidario de eliminar la familia 50 . Por su parte, el indiscutiblemente progresista sacerdote José Luis Martín Descalzo dejó claro en un artículo publicado en $A B C$, que los obispos no estaban contra el divorcio, sino contra "unas determinadas claúsulas de una ley» 51.

El 3 de febrero de 1981 se hacía pública su «Declaración de la Comisión Permanente de la Conferencia Episcopal Española sobre el Proyecto de Ley de modificación de la regulación del Matrimonio en el Código Civil» 52. El principal blanco de los ataques era el llamado «divorcio consensual", ya que se consideraba que éste dejaba la pervivencia del vínculo matrimonial practicamente a la simple disposición de los cónyuges, con lo cual la unión quedaba en un estado de máxima fragilidad donde los

49 Fernández Ordóñez, F.: Palabras en..., op. cit., págs. 80 y 81. Sin embargo, Ecclesia quiso hacer ver a sı!s lectores que probablemente se habia llegado a un pacto entre ambas partes. Véase al respecto el número 2017, 7 de febrero de 1981, pág. 20.

$50 \mathrm{Ya}, 30$ de enero de 1981, pág. 24.

$51 A B C, 31$ de enero de 1981, pág. 21.

52 Ecclesia, núm. 2017, 7 de febrero de 1981, págs. 14 y 15. 
principales perjudicados eran el cónyuge más débil y los hijos. Recordando siempre que la censura no iba contra la idea en si de una ley del divorcio, sino contra determinados aspectos, se afirmaba que el proyecto era rechazable desde el punto de vista moral.

El primero en lamentar todo el enfrentamiento entre la Iglesia y la clase política fue el propio Iñigo Cavero, quien, con sus declaraciones a Ya del 5 de febrero de $1981^{53}$, dejó patente el consenso que hasta la llegada de Fernández Ordóñez a Justicia había imperado entre el Gobierno y la jerarquía. Ciertamente, el conflicto del divorcio y la declaración episcopal no podían llegar en peor momento. Suárez había dimitido como presidente del Gobierno el 29 de enero, y el 6 de febrero daba inicio el II Congreso de la UCD, donde definitivamente se confirmó la pérdida de liderazgo del político abulense. Calvo-Sotelo sería el nuevo presidente del Gobierno, no sin antes tener que pasar por el más bochornoso episodio de la joven democracia española (el pronunciamiento del 23-F). Sería, por cierto, también tiempos de cambio (muy moderado) en el seno de la jerarquía católica, pues el mismo dia en que Tejero tomaba el Congreso de los Diputados, Enrique y Tarancón dejaba la presidencia de la Conferencia Episcopal en beneficio de Gabino Díaz Merchán.

Pero, ¿cuál era realmente el nivel de demanda de la ley del divorcio? Si tenemos que seguir a Inés Alberdi, la opinión más generalizada entre los españoles es que el divorcio podía concederse, aunque no en cualquier caso (55\%), lo cual no evitaba que casi cuatro de cada diez españoles $(37 \%)$ lo viera como algo inmoral ${ }^{54}$. Diario 16 realizó una encuesta en febrero de 1981 según la cual los que se oponían con más fuerza al divorcio eran los «católicos muy poco practicantes» $(61 \%$ en contra y $39 \%$ a favor), mientras que entre los «católicos poco practicantes» el número de los que estaban a favor subía al $73 \%$, cifra que llegaba al $86 \%$ entre los "católicos no practicantes" 55 . Cambio 16 , perteneciente al mismo grupo que Diario 16, completó estos datos con una nueva encuesta en mayo de 1981, a sólo un mes de la aprobación de la ley, según la cual

53 Ya, 5 de enero de 1981, pág. 20. «Desde que conocí el dictamen de la Comisión de Justicia sobre el proyecto de ley... esperaba esta declaración episcopal, que me preocupa mucho por las posibles tensiones de tipo religioso y político que puede producir. Mientras tuve la responsabilidad de conducir el proyecto de ley, todos mis esfuerzos se orientaron precisamente a evitar este tipo de tensiones, tomando como guía o base el programa electoral de UCDn. En esto último Cavero concordaba, en parte, con Marcelo González, quien había recordado a Fernández Ordóñez quiénes eran y qué querían los electores gracias a los cuales él era ministro de Justicia.

54 Alberd, I.: Historia y sociología del divorcio en España. Madrid, ClS, 1979, pág. 128. 55 Diario 16, 6 de febrero de 1981, págs. 10 y 11. 
casi el $30 \%$ de los católicos eran partidarios del que el divorcio se concediera en cualquier circunstancia, mientras un $42 \%$ ponía algunas condiciones ${ }^{56}$. Por lo tanto, la opinión pública no respaldaba tampoco con especial fuerza el proyecto de Fernández Ordóñez.

Aunque la jerarquía, como ya hemos señalado, no hizo practicamente nada por obstaculizar el proceso, los católicos de a pie, en particular los más conservadores, se movilizaron para evitar lo que parecía inevitable. Además, jurídicamente se encontraban secundados por el libro que habían publicado tres canonistas, Lamberto de Echevarría (perteneciente a la Universidad Pontificia de Salamanca), Carmelo de Diego (Navarra) y Carlos Corral (Comillas), titulado El nuevo sistema matrimonial y el divorcio, y donde se hablaba de inconstitucionalidad de la norma, ya que la Constitución de 1978 reconocía la libertad de contraer matrimonio civil y canónico y la ley convertía éste, de facto, en un matrimonio civil, además de que la Constitución se había comprometido a salvaguardar una estabilidad de la familia contra la que la ley atentaba). No obstante, los católicos más radicalmente contrarios al divorcio no poseian la suficiente fuerza para cambiar el rumbo de la situación, y el tiempo se encargó de demostrarlo.

Calvo-Sotelo es el primero que reconoce que no recibió personalmente ningún tipo de presiones por parte de la jerarquía. Sí de un miembro de ésta (Ángel Suquía) 57, pero nunca de ella de manera

56 Cambio 16, núm. 492, 4 de mayo de 1981, págs. 28-33.

57 El que fuera segundo presidente de la democracia española lo cuenta con su peculiar y agudísimo sentido del humor a la periodista Victoria Prego: "Yo no tuve una sola presión oficial de la jerarquía. Y la Ley del Divorcio, cosa que a veces se olvida, se fomenta íntegramente siendo yo presidente, en el parlamento, en la comisión y en el pleno. Sí tuve en cambio la presión personal de un hombre que luego fue cardenal, Suquia, con quien yo tenia una relación antigua, no de amistad, porque yo nunca he tenido amigos curas ni militares, no sé por qué. Yo no tenía relación con él. Además, él estaba en Santiago, y yo era presidente del Gobierno.

El caso es que (no recuerdo cuál era en ese instante el momento procesal de la ley, pero desde luego la ley estaba entonces en el pariamento) me llama a Ribadeo. Yo estaba pasando alli unos días y me dice (además mentia, aquí todos mentimos, y Suquía también): "Voy en visita pastoral a Ribadeo y me gustaria verte". Y yo le digo: "Angel, no invente usted cosas, Ribadeo no es de su diócesis, Ribadeo es de Mondoñedo, de lo cual estamos todos muy orgullosos, y no queremos saber nada de Santiago, de manera que si usted quiere venir a Ribadeo le invitaré con mucho gusto. Véngase a casa y comemos". Entonces vino a casa a comer. En la comida estaban los chicos, y luego charlamos unos quince minutos aparte. Y me dice: «Personalmente, por mi afecto por ti no quiero que hagas cosas que, en fin, tal y cual", era casi como si fuera mi confesor, ¿no?

De modo que sí, me presionó en el sentido civil: «Hombre, esto del divorcio no lo hagáis, todavia estáis a tiempo... Pero nunca, eso lo dejó bien claro, metió a la jerarquía; la jerarquia es otra cosa». Prego, V.: Presidentes. Barcelona, Círculo de Lectores, 2000, págs. 162 y 163. 
institucional, porque ésta prefirió mantenerse al margen en la medida de sus posibilidades.

Tras el golpe de Estado fallido del 23 de febrero de 1981, Fernández Ordóñez era confirmado en su puesto en el primer gobierno Calvo-Sotelo. En los cuatro meses que transcurririan hasta la aprobación de la ley, el ambiente se haría casi irrespirable para el político socialdemócrata: en una afirmación con bastante poco sentido, se llegó a decir que el estamento militar se encontraba muy intranquilo ante una posible aprobación de la ley, como si ésta hubiera tenido un protagonismo significativo en la asonada de Tejero 58.

La crítica fundamental hacia la gestión de Fernández Ordóñez no debe dirigirse hacia la necesidad o no de la ley del divorcio, cuestión que resulta bastante discutible: no la existencia en sí de ésta, porque era evidente que España tenía que adaptarse a la modernidad y casi todos los estados europeos poseían una ley del divorcio, sino sobre si ésta debía facilitar en la medida de lo posible la ruptura de la unión conyugal o si, por contra, como admitía la Iglesia y como exigían los democristianos, era obligación suya hacer posible el divorcio cuando éste fuera estrictamente necesario. Lo que nosotros criticamos abiertamente de Fernández Ordóñez es que rompió en toda regla la disciplina del partido cuando ésta era precisamente la que le había colocado en el gobierno: es decir, si admitimos que de la reunión de la "casa de la pradera» había salido la imposición sobre Suárez de una política de pactos entre las distintas familias ideológicas (democristianos, socialdemócratas, azules, liberales...), y que, en función de ello, Fernández Ordóñez había podido exigir a su líder la cartera de Justicia, éste no tenía derecho a ir por libre dentro del gobierno, por muy progresista que él tratara de presentarse a sí mismo y ante la opinión pública.

No nos ha de extrañar, por tanto, la indignación con la que Herrero de Miñón, diputado de la UCD y portavoz parlamentario de su partido desde finales de 1980, reacciona al referirse al asunto del divorcio. Herrero ya había defendido la necesidad del divorcio desde que era secretario general técnico de Justicia con Landelino Lavilla como ministro del

58 Fernández Ordónez, F.: Palabras en..., op. cit., págs. 79 y 80. «Aumentaron los escritos anónimos insultantes (llegaron a ser casi cien cada día) y comenzaron las llamadas telefónicas en el mismo sentido. La antigua caverna española resucitó su clásico sistema de calumnia organizada y circuló la idea de que yo defendía la ley del divorcio porque me quería divorciar..." 
ramo, y no niega la idea de que la UCD era en su mayoría partidaria de una ley del divorcio 59 . Sin embargo, considera que se produjo una instrumentalización política de la misma, pues los socialdemócratas tendieron una trampa a los democristianos (encabezados por Álvarez de Miranda y Alzaga) con el objetivo, según él, de «humillar a los sectores más conservadores» 60 . Lo primero que hizo Herrero fue asegurarse de cuál era la posición de la Iglesia jerárquica al respecto, encontrándose con que, mientras Enrique y Tarancón no se oponía a la misma (reafirmándose en la necesidad de la separación Iglesia-Estado), el Nuncio Innocenti no se dignaba a recibirle (muy seguramente contrariado por el vuelco a la situación que Fernández Ordóñez había dado) e igual hacía Díaz Merchán (quien prefirió mantenerse incomunicado). Ante tal realidad, Herrero decidió que lo mejor era buscar el apoyo de su propio partido. Y ese apoyo le llegó, porque, tras una durísima sesión plenaria del grupo parlamentario, celebrada el 11 de marzo de 1981, José Antonio Escartín, defensor del proyecto de Cavero, salió vencedor frente a Moscoso. En contra de la opinión de dos hombres importantes del partido, Fernando Abril Martorell y Rafael Arias-Salgado, Herrero propuso hacer una votación interna ${ }^{61}$, que no menciona Fernández Ordóñez ${ }^{62}$, según la cual el sesenta por ciento de los diputados optaron por volver al proyecto de Cavero. Todo se dejó en el aire hasta la reunión de la Ejecutiva del partido, hecho que se produjo el 16 de marzo, y de la cual salió una especie de solución conciliadora: se volvería al proyecto de Cavero, pero se dejaba la puerta abierta a una serie de modificaciones en el trámite senatorial. La citada solución fracasó en toda regla, porque Fernández Ordóñez y los socialdemócratas seguían obstinados en llevar a

59 La propia ristoriografia lo señala en los estudios de HUNneUS, C.: La Unión de Centro Democrático y la transición a la democracia en España. Madrid, CIS, 1985, págs. 339-347; y GUNTHER, R.: «EI hundimiento de UCD», en LINZ, J. J. y MONTERO, J. R. (Eds.): Crisis y cambio: electores y partidos en la España de los años 80. Madrid, Centro de Estudios Constitucionales, 1986, págs. 477 y 478.

60 Herrero de Miñón, M.: Memorias de estío. Madrid, Temas de Hoy, 1993, pág. 257.

61 Aunque puede ser un elemento discutible, Herrero asegura en sus memorias que él nunca se ha considerado integrado en la democraciacristiana. Ibidem, pág. 257.

62 Sí reconoce, no obstante, la existencia del debate en lo que él llama una "ofensiva perfectamente preparada" contra su proyecto. En la supuesta "ofensiva" tomaron parte José Luis Álvarez, Iñigo Cavero, Otero Novas, Diez Piniés, Meilán, de Grandes, Gómez Angulo, Martín Oviedo, Gabriel Cisneros y, muy especialmente, Alzaga. El resultado fue nulo, pues se dejó todo a la espera de lo que decidiera la Comisión Ejecutiva del partido. De todas maneras, el ministro de Justicia iba totalmente por libre, porque, de hecho, reconoce lo siguiente sobre aquel día: «En cualquier caso, yo anuncié que mi voto seguiria siendo el del texto de la Comisión del Congreso", que no era otro que el suyo. Fernández Ordóñez, F.: Palabras en..., op. cit., pág. 80 . 
buen puerto su proyecto, no teniendo problemas en romper la disciplina del partido 63.

De hecho, sólo un día después, el 17 de marzo de 1981, Fernández Ordóñez presentaba al Congreso su proyecto de ley 64 . Comenzó su discurso afirmando que se habían producido cambios fundamentales en la estructura de la familia, que había pasado de ser unidad de producción a unidad de consumo. Los roles y las actitudes también habian sufrido una transformación, hasta el punto de que la libertad sexual había sido en su tiempo lo que en otros momentos fue la libertad de pensamiento (algo que calificó de revolucionario). Las tasas de nupcialidad, según él, se habían desplomado, aumentando el número de las parejas de hecho y las relaciones con hijos extramatrimoniales, además de que el número de hijos había descendido. Al mismo tiempo, recordó la aconfesionalidad sobre la que pretendia asentarse la ley del divorcio, y que el hecho de que hubiera una mayoría católica no podía esgrimirse como motivo para evitar el cambio; en cualquier caso, no sería esta ley la culpable de la crisis familiar, sino más bien otras causas 65 .

A su parecer, once eran las novedades fundamentales que aportaba su proyecto: se atribuían los mismos efectos civiles a todos los matrimonios celebrados con arreglo a las confesiones religiosas inscritas en el Registro y no sólo a la católica (1); se recogía la separación judicial por

63 Recuerda Herrero: “Entre tanto había tenido lugar muy tormentosas sesiones en el Congreso, en el que el sector socialdemócrata y el ministro Fernández Ordóñez se complacieron no tanto en una fórmula específica divorcista como en violar los acuerdos formalmente tomados en el propio Congreso de Palma, la Ejecutiva del partido y el grupo parlamentario. A la vez, era la mayoría de los diputados y yo, como encargado de hacer valer sus derechos, quienes éramos acusados de indisciplina por exigir simplemente que nos atuviéramos a los criterios adoptados por las instancias competentes". HERRERO DE MiÑón, M., op. cit., pág. 260.

64 Su intervención completa se encuentra contenida en el Diario de Sesiones de las Cortes. 17 de marzo de 1981, págs. 9392-9397.

65 Ibidem, pág. 9393. Sus palabras resumen muy bien lo que él interpretaba por nueva realidad Iglesia-Estado: "esta Ley del Divorcio se asienta en el principio de aconfesionalidad del Estado y de libertad de religión y de creencia. Que la ley es así, solamente imperativa para aquellos que hacen uso de ella; que es una ley que permite hacer, que no obliga a hacer, que atribuye derechos, que simplemente autoriza.

$\mathrm{Ni}$ el Estado puede imponer a todos los miembros de la colectividad unas exigencias morales o religiosas que sólo afectan a la conciencia de una parte de ella, aunque sea mayoritaria, ni puede quebrarse la unidad del ordenamiento jurídico por razones de estas creencias. No tiene, por tanto, sentido la negativa al divorcio basada en la defensa de la familia. A la familia la ha deshecho mucho antes el desamor, el abandono, el adulterio, el desamparo. Como consecuencia de esta ignorancia y de una filosofía antidivorcista, ha florecido en España una situación gravísima de alegalidad, de situaciones de hecho, de anomia". 
mero acuerdo de los cónyuges, sin más requisitos (2); se reducían los plazos de divorcio a la mitad (3); se trataba el problema del cónyuge que había sido culpable o abandonante, dándosele el derecho a consolidar su situación, para lo cual se manejaba un plazo de cinco años (4); se recogía el caso de divorcio directo por atentado a la vida de otro cónyuge (5); se contaban los plazos del divorcio no a partir de la admisión de la demanda, sino de la interposición de la demanda de separación previa, fijando el plazo máximo previo a la demanda de divorcio en un año (6); en beneficio de las parejas donde el cese efectivo de la convivencia obligara a adquirir una segunda residencia sin posibilidades económicas para ello, se permitía, con la consiguiente carga de prueba, que fuera compatible con el mantenimiento de vida en el mismo domicilio (7); se aplicaría la claúsula de dureza sólo cuando lo pidiera el cónyuge abandonado o inocente, con un límite en el tiempo, y quedando limitado también en el arbitrio judicial a casos tasados o gravísimos (8); se respetaba el principio de que el juez oyera en todo caso a los hijos mayores de doce años y que no se separara, si es posible, a los hermanos (9); se agilizaba de manera importante el procedimiento, evitando obstáculos innecesarios y costes judiciales para el caso de que ambos cónyuges presentaran la demanda de divorcio de común acuerdo (10); y se extremaba la precaución por las consecuencias económicas del divorcio, protegiendo a la parte más débil en materia de pensiones y seguridad social 66 .

El final de su discurso es un tanto demagógico e incluso puede ser calificado de contradictorio, pues apela a la necesidad de recuperar la herencia de Fernando de los Ríos, también ministro de Justicia como él y el único que consiguió aprobar una ley del divorcio, cuando el olvido de lo que fue la tormentosa gestación de la Constitución de 1931 estuvo siempre presente a lo largo de la discusión de la Carta Magna de 197867.

El espaldarazo fundamental al proyecto del ministro de Justicia se dio pocas semanas después, concretamente en la sesión parlamentaria del 2 de abril de 1981. La discusión principal se dio en torno al artículo $87^{68}$. La

66 Ibidem, págs. 9396 y 9397.

67 Resulta interesante, en este sentido, comparar el tono de Fernando de los Ríos en 1931 con el de Fernández Ordóñez cincuenta años después, especialmente en lo referido a todo el tema religioso. Reflejaba perfectamente la siperación del enfrentamiento religioso que hizo calificar a la Guerra Civil de Cruzada. Veáse al respecto Martín de SANTA OLALLA SALUDES, P.: «Fernando de los Ríos y la "cuestión religiosa" en las Cortes de 1931", en CAMARA VILLAR, G. (ed.): Fernando de los Ríos y su tiempo. Granada, Universidad de Granada, 2000, págs. 567-579.

58 Decía así: "Cuando el divorcio se funde en el cese efectivo de la convivencia conyugal, a que se refieren los artículos 82,6, y 86,4 , de este Código el Juez, a petición del otro cónyuge, 
ausencia deliberada de algunos parlamentarios de la UCD y el total apoyo de la oposición de izquierdas hizo posible la eliminación de la llamada "claúsula de dureza» 69 , principal obstáculo del llamado «divorcio consensual», provocando una fuerte bronca en el grupo parlamentario centrista ${ }^{70}$. No es de extrañar, porque, si seguimos a Herrero de Miñón ${ }^{71}$, el grupo parlamentario que él encabezaba se había reunido de nuevo entre el 16 de marzo y el 2 de abril y había acordado mantener en el Congreso de los Diputados el texto primitivo en cuanto a la claúsula de dureza se refería, remitiéndose el resto al Senado.

En este sentido, resulta un tanto incomprensible la actitud del presidente Calvo-Sotelo ante todo lo que estaba sucediendo. Porque Fernández Ordóñez, al actuar como lo estaba haciendo, estaba violando las resoluciones del Congreso de Palma, los acuerdos de la Ejecutiva del partido y del grupo parlamentario de la UCD. Sin embargo, Calvo-Sotelo le mantuvo contra viento y marea, no sabemos si con el fin de evitar una fractura en el partido (aunque precisamente permitiéndole que llevara a cabo sus propósitos consiguió el efecto contrario) o porque él también estaba de acuerdo con una ley del divorcio como la que finalmente se aprobó. Lo cierto es que, como veremos más adelante, Fernández Ordóñez no fue cesado, sino que se marchó.

Por otra parte, Herrero de Miñón, como portavoz del grupo parlamentario, había intentado jugar a finales de marzo una última carta, que fue recordar los recientemente firmados acuerdos con la Santa Sede: su carácter interpotestates los hacía parte del ordenamiento interno español, por lo que eran intocable para el propio legislador ordinario según lo habia previsto la Constitución 72 . Lo dijo en una nuevamente tormentosa

podrá denegar el divorcio si se acredita que causa perjuicio de extraordinaria gravedad a los hijos menores o incapacitados o al cónyuge habida cuenta de su edad, estado de salud o la duración del matrimonio, supuestos en los que deberá fundarse la sentencia. No podrá denegarse el divorcio por esta causa, cuando el cese efectivo de la convivencia hubiere durado más de siete años". Boletín Oficial..., op. cit., págs. 868/29-868/30.

69 El artículo 87 fue finalmente suprimido. Sobre 236 votos emitidos, 108 fueron favorables, 121 negativos y se dieron 7 abstenciones. Sobre las discusiones en torno a éste, veáse Diario de Sesiones del Congreso, 2 de abril de 1981, págs. 9702-9710.

70 La narración de lo que sucedió la encontramos en $A B C, 3$ de abril de 1981, págs. 5 y 6.

71 Herrero de Miñón, M., op. cit., pág. 260.

72 Resulta muy interesante esta afirmación de Herrero de Miñón, porque Fernández Ordóñez, al obstinarse en que se aprobara su proyecto, estaba provocando un conflicto de carácter diplomático. Porque en uno de los acuerdos parciales de 1979, concretamente en el concerniente a los asuntos jurídicos, el Gobierno español se habia comprometido en su artículo VII a no legislar de manera unilateral en aquellos asuntos de carácter polémico. El mismo Díaz Moreno que 
sesión parlamentaria celebrada el 24 de marzo, pero el portavoz socialista Virgilio Zapatero, valiéndose de to que Herrero califica como «el más reaccionario de los criterios", afirmó la primacía del derecho interno sobre cualquier obligación internacional 73: su victoria sobre Herrero de Miñón fue rotunda, entre otras cosas porque contó con el apoyo de no sólo la izquierda, sino también de los socialdemócratas e incluso de los suaristas 74 .

No obstante, la inestabilidad de la UCD volvió a ponerse de manifiesto en el 25 de mayo, esta vez en el Senado: la "claúsula de dureza» era reincorporada. Lo que llevó al ministro de Justicia a maniobrar con habilidad, consiguiendo que el Congreso, a través de una votación secreta 75 , eliminara de manera definitiva la "claúsula de dureza". Para ello contó con el voto a favor de la supresión del artículo 87 de 162 diputados, mientras 128 lo hacian en contra y 7 votaban en blanco. Como consecuencia de la citada votación, el artículo 86 bis que habia sido aprobado previamente, pasó a ser el artículo 87 en el Código Civil.

Fernández Ordóñez era el vencedor final, pero ello le costó la enemistad de un sector de la Iglesia, entre ellos del propio Cardenal Primado de Toledo, quien se tomó cumplida venganza del proyecto divorcista. El día 18 de junio, faltando sólo cuatro días para que la ley fuera aprobada, se

en su momento había dado un dictamente jurídico favorable a una ley del divorcio acusaría, una vez comprobada la importante transformación que había sufrido el proyecto divorcista, a la UCD de haber violado los acuerdos entre la Santa Sede y el Estado español. Ecclesia, núm. 2025, 4 de abril de 1981, pág. 23.

73 HerRero de MiÑón, M., op. cit., págs. 260 y 261. También Diario de Sesiones del Congreso de los Diputados, 24 de marzo de 1981, págs. 16 y ss.

74 Los suaristas no habian encajado la derrota de Adolfo Suárez en lo que se refiere a la elección del portavoz del grupo parlamentario de UCD. Aunque el presidente del Gobierno habia propuesto a Santiago Rodríguez Miranda. Herrero de Miñón dio la sorpresa y, en la votación celebrada el 14 de octubre de 1980, se impuso por 103 votos a 45 . Se trataba de un derecho legítimo, pero los suaristas, principales veladores por la unidad del partido, vieron ya desde entonces a Herrero como uno de los principales culpables de la fragmentación de la UCD.

75 Herrero fue acusado por Fernando Abril Martorell y Rafael Arias-Salgado de torpeza en el manejo del reglamento y, por ello, de ser el culpable de que no se hubiera hecho una votación pública, lo cual impidió saber quien en la UCD había votado a favor y quién en contra. Asegura el exdiputado que él había solicitado una votación pública de las enmiendas del Senado, pero que Landelino Lavilla, presidente de la Cámara Baja, y Fernández Ordóñez habían acordado que fuera secreta. Al haberse desatado una campaña de prensa difamatoria contra Herrero, éste escribió sendas cartas a Calvo-Sotelo, coma presidente del Gobierno, y a Rodríguez Sanagún, como presidente de la UCD (ya con la ley aprobada), donde les amenazaba con dar testigos y pruebas a la prensa para que se conociera la auténtica verdad. Cierto o no (porque no conocemos más versiones), el hecho que constatamos es el fin de la campaña contra Herrero. 
celebró en Toledo la festividad del Corpus Christi, en la cual se incluye una procesión a la que tradicionalmente asistía el ministro de Justicia. Pero ya para aquel día Marcelo González había escrito a Calvo-Sotelo para dejarle claro que un divorcista como Fernández Ordóñez no podía participar en el acto. No sólo no iba a poder tomar parte en la procesión, sino que tampoco podría asistir a la misa en la catedral, y así fue, viéndose obligado Fernández Ordóñez a ver la procesión desde la sede del Gobierno Civil en Toledo. En realidad, sin quererlo ninguna de las dos partes, no se había cumplido la voluntad del Cardenal Primado, sino la propia Constitución: en un estado aconfesional como el español no tenía sentido la participación de un miembro del gobierno en un acto religioso como parte fundamental del mismo, porque la Iglesia y el Estado iban ya por separado. Por otra parte, no era el primer desaire que Fernández Ordóñez sufria por parte de la jerarquía, pues al mes de haber jurado como ministro de Justicia, concretamente el 12 de octubre, festividad del Pilar, Elías Yanes, Arzobispo de Zaragoza, había pronunciado una homilía muy dura contra el divorcio delante del propio Fernández Ordóñez, al que le molestó que éste no le hubiera avisado 76 .

El 22 de junio el proyecto divorcista alcanzaba rango de ley gracias a los votos de los socialdemócratas de la UCD, PSOE, PCE, Minoria Catalana, Esquerra Republicana de Catalunya y PNV, votando en contra el resto de los diputados de la UCD y los de Alianza Popular. El caso era tan insólito que no han de extrañarnos ni las palabras de Óscar Alzaga («Esto es un fraude a nuestro electorado, y creo que la única manera de saldar una maniobra como ésta es exigiendo ahora mismo del presidente del Gobierno, Leopoldo Calvo-Sotelo, la dimisión del ministro de Justicia, Francisco Fernández Ordóñez" 77) ni la de Fernando Álvarez de Miranda («Estas cosas evidencian que la unidad de la UCD es una farsa. Podemos ser una coalición, pero nunca un partido, ya que los modelos de sociedad que sostenemos los demócratacristianos y los socialdemócratas son demasiados distintos" 78 ). La Iglesia, por su parte, se sintió traicionada, porque no había obstaculizado la tarea del gobierno y, sin embargo, éste se lo habia pagado con una ley mucho más perjudicial para sus intereses 79 . Como era de esperar, Fernández Ordóñez tardó sólo dos meses en dimi-

76 Fernández Ordóñez, F.: Palabras en..., op. cit., pág. 77. "Había comenzado la ofensiva", recordaría el ministro.

77 El País, 23 de junio de 1981, pág. 18.

78 lbidem, pág. 18.

79 El Cardenal Enrique y Tarancón, a pesar de que en el momento de aprobarse la ley ya no era el líder de la Iglesia católica española (había dejado su puesto en febrero de 1981 a Gabino 


\section{tir como ministro de Justicia (finales de agosto) ${ }^{80}$, tras lo cual abandona- ría la UCD junto con otros 16 parlamentarios socialdemócratas (diciem-}

Díaz Merchán), aseguró sentirse «engañado por Fernández Ordóñez». HERnÁNDEZ, A., op. cit., pág. 148. Son unas declaraciones personales de las que no tenemos constancia segura de su existencia. En cualquier caso, declaró a María Mérida en 1982: «Ningún cristiano, si es coherente con su fe, puede acogerse a una ley de divorcio. La autoridad civil debe tener en cuenta su gran responsabilidad si admite ese mal que, según confirma la experiencia, es causa y raiz de muchos males en el orden familiar y social’. MÉRIDA, M., op. cit., pág. 92.

80 A pesar de que Alzaga, como hemos señalado anteriormente, había exigido públicamente a Calvo-Sotelo la dimisión de Fernández Ordóñez, éste se marchó voluntariamente, llevando a cabo un último acto de infidelidad hacia la UCD y, en concreto, hacia un presidente del Gobierno que le había protegido y mantenido en el cargo contra viento y marea. Recuerda Calvo-Sotelo que el día 30 de agosto de 1981 reunió, una vez pasadas las vacaciones, a un grupo de ministros, entre los que se contaba Fernández Ordóñez, para preparar el nuevo curso. El todavía ministro de Justicia participó activamente, como si nada fuera a pasar. Pero al día siguiente, lunes 31, Calvo-Sotelo se encontró encima de su mesa la carta de dimisión del socialdemócrata. El presidente le solicitó una semana de reflexión y de conversaciones entre ambos para ver si no habia otra salida, algo que Fernández Oróónez aceptó. Pero la nueva y última infidelidad se consumó a las doce de ese mismo día, cuando el rumor de su dimisión comenzó a circular por los teletipos. Ante la imposibilidad de localizarle (suponemos que perfectamente calculada por Fernández Ordóñez), Calvo-Sotelo decidió cesarle fulminantemente y ofrecer su cartera a Antonio Garrigues Walker, aunque el que finalmente ocupó el puesto fue Pio Cabanillas. De todas maneras, y continuamos leyendo a Calvo-Sotelo, Fernández Ordóñez ya estaba bajo sospecha desde hacía mucho tiempo, concretamente desde 1977. Basten dos testimonios. El primero, de CalvoSotelo, dice lo siguiente: "Ya en el mes de mayo de 1977, cuando me tocó el duro oficio de hacer las primeras listas electorales para UCD, Fernández Ordóñez anduvo entrando y saliendo en la nueva disciplina como hombre inevitablemente fronterizo que es. Le espantaba la presencia de tantos azules en las listas, a él que habia tenido puestos políticos en tiempos azules, y dudó hasta el último momento si aceptaba o no entrar con sus menguadas huestes en la coalición centrista. La misma duda tenía respecto de él Adolfo Suárez, a quien yo informaba sobre la complejisima negociación de las candidaturas, y que me dijo más de una vez: «Deja a Paco y a los suyos fuera»" (CAlvo-Sotelo, L.: Memoria viva de la Transición. Barcelona, Plaza\&Janés/Cambio 16,1990, pág. 206. El segundo testimonio corresponde a Altonso Osorio, vicepresidente segundo del Gobierno y ministro de la Presidencia entre julio de 1976 y julio de 1977, quien recuerda también aquellos meses previos a la celebración de las primeras elecciones democráticas con las siguientes palabras: hablando sobre una reunión que mantuvo con Suárez el 2 de mayo de 1977, le aseguró al presidente que no era «conveniente una presencia excesiva de socialdemócratas. Me ha preguntado por qué, y le he dado mis razones: "En el futuro (le he dicho), para que nuestra política sea estable, es necesario que cada uno esté en su auténtico lugar. Los políticos como Francisco Fernández Ordóñez van a estar siempre con propensión hacia el Partido Socialista, lo cual, por la propia fuerza de las cosas, va a ser un semillero de problemas».» (Osorıo, A.: De orilla a orilla. Barcelona, Plaza\&Janés, 2000, pág. 341). Ni Calvo-Sotelo ni Osorio se equivocaban. De hecho, en un famoso pleno parlamentario que se celebró en septiembre de 1977, Alfonso Guerra retó, con motivo del incidente «Blanco» (un diputado socialista que había sido golpeado por una policía durante una manifestación), a Joaquín Garrigues Walker y a Francisco Fernández Ordóñez para que dejaran públicamente en evidencia las supuestas veleidades autoritarias de Martín Villa. Mientras Garrigues, líder de los liberales de 
bre de 1980), entre ellos los ya citados Luis González Seara, Javier Moscoso y Maria Dolores Pelayo ${ }^{81}$. Según González Seara, la idea de fundar el Partido de Acción Democrática (PAD) tenía como objetivo el funcionar como partido «bisagra" para evitar tener que recurrir siempre a los partidos nacionalistas ${ }^{82}$, pero al final lo único que sucedió es que se convirtieron en sirvientes de los intereses del PSOE. Sin embargo, todo tuvo su recompensa: Fernández Ordóñez seria ministro de Asuntos Exteriores de Felipe González durante nada menos que cinco gobiernos socialistas, desde julio de 1985 hasta junio de 1992, en que su fallecimiento dio paso a Javier Solana.

La Iglesia hizo pública una declaración durante la celebración de la asamblea de la Conferencia Episcopal que hubo a finales de junio donde volvía a recordar lo perjudicial que la ley era para la estabilidad de la familia. Sin embargo, como recuerdan José Andrés-Gallego y Antón Pazos, el debate en torno al divorcio se dio practicamente por cerrado a partir de ese instante, al contrario de lo que sucedería dos años después con el aborto ${ }^{83}$. Poco tiempo después (en diciembre de 1981) se supo el alcance real de la nueva ley: las demandas de divorcio no habian aumentado más que en cinco mil en los meses siguientes (hablamos de septiembre a diciembre, porque julio y agosto son meses vacacionales), tan sólo un $1 \%$ de lo que había previsto el propio Fernández Ordóñez ${ }^{84}$. Cuando Eduardo García Rico le preguntó si había merecido la pena "tanto ruido para treinta mil divorcios en seis meses", sólo se le ocurrió responder que no todos los matrimonios fracasados acudían al divorcio, sino sólo los que se veían abocados a ello o los que querian volver a casarse ${ }^{85}$.

la UCD, se levantó de su asiento para sentarse al lado de Martín Villa, Fernández Ordóñez no quiso mostrar su solidaridad para con su compañero de partido. De él recordaría el exministro de Interior: "Ya desde el principio Fernández Ordónez tenía un ojo en la prensa y otro en la izquierda". MARTín VILLA, R.: Al servicio del Estado. Barcelona, Planeta, 1984, pág. 127 y pág. 146.

81 Fernández Ordónez, F.: Palabras en..., op. cit., pág. 81. "Yo no podía continuar en un partido en el cual todos los puntos de vista que yo defendía tenían que hacerse precisamente contra los de ese partido. Los ataques más fuertes no vinieron de Alianza Popular sino de filtraciones, insidias o enfrentamientos en el interior de UCD".

82 Navarao, J.: Nosotros, la Transición. Madrid, Temas de Hoy, 1995, pág. 389.

83 Andá́s-Gallego, J. y PAzos, A. M.: La Iglesia en la España contemporánea. Vol. II, 19361999, Madrid, Ediciones Encuentro, 1999, pág. 220.

84 Presidencia del Tribunal Supremo: Encuesta sociológica sobre la aplicación de la ley del divorcio. Madrid, 1981, págs. 5 y 8.

85 Fernández Ordónez, F.: Palabras en..., op. cit. pág. 85. 
El conflicto en torno al divorcio nos permite extraer una serie de conclusiones. En primer lugar, desconocemos si la intención de Fernández Ordóñez y de los socialdemócratas era provocar la fragmentación del partido, o tener la justificación para abandonar un barco, el de la UCD, que se hundía irremisiblemente: en cualquier caso, poseen gran parte de culpa del desastre final y no fueron precisamente perjudicados por tal desastre, pues no sólo Fernández Ordóñez, sino otros, como Moscoso, encontraron muy buen acomodo en las filas del PSOE cuando éste llegó al poder. En segundo lugar, la ley finalmente aprobada ni respondía a las exigencias de la sociedad española ni era lo suficientemente importante como para provocar toda una crisis de gobierno, porque el número de divorciados que se acogieron a la nueva realidad legal fue muy inferior al previsto por Fernández Ordóñez. En absoluto ha potenciado la unidad de la familia, entre otras cuestiones porque, al tiempo que ha facilitado al máximo la ruptura de la unión conyugal, las nuevas generaciones de españoles no se encuentran influidas por si la ley de Cavero o Fernández Ordóñez se adaptaba mejor o peor a sus necesidades, sino más bien por otro tipo de coyunturas, entre ellos la notable pérdida de presencia del catolicismo en la vida de los ciudadanos. En tercer lugar, la Iglesia, más en concreto la jerarquía católica, actuó con una tolerancia muy importante (insisto, teniendo siempre presente su sistema de creencias), pues, como hemos podido comprobar, hasta que Fernández Ordóñez decidió dar un vuelco total a la situación, apenas obstaculizó el proyecto divorcista, y eso que razones doctrinales, incluso evangélicas, no le faltaban para ello: con la Ley del Divorcio, los obispos españoles antepusieron la separación Iglesia-Estado a cualquier consideración de orden moral, lo que la autoridad política debe reconocer como un notable gesto hacia las instituciones democráticas. En cuarto lugar, Fernández Ordóñez demostró un claro talante oportunista: mientras le convino la disciplina de partido, la aceptó (ella le llevó a la cartera de Justicia), pero, cuando ésta le perjudicó, no tuvo problemas para romperla, aunque cierto es que como ministro, legalmente, no estaba obligado a seguir ninguna orden de su partido. Curiosamente, como ministro de Asuntos Exteriores del PSOE, no volvería a provocar ningún altercado. En quinto y último lugar, la Ley del Divorcio supone una auténtica victoria del sistema parlamentario, tradicionalmente sujeto a que el partido que esté en el poder pueda sacar adelante las leyes en ambas cámaras: por una vez, una ley que no pertenecía al gobierno ni al partido dominante, sino sólo a una minoría dei mismo, salió adelante gracias fundamentalmente a los votos de la oposición. Pocas veces se ha repetido un hecho semejante, y este tipo de hechos dotan de más sentido que nunca tanto al Congreso como al Senado. 
Ironías del destino. El día en que fue aprobada la ley, el 22 de junio, era, al mismo tiempo, el de las festividades de San Juan Fisher y Santo Tomás Moro, ambos mártires de la Iglesia por haberse opuesto al divorcio de Enrique VIII. Pero también era el día en que Fernández Ordóñez cumplía 51 años. 